\title{
Marketing Chain of Smallholder Robusta Coffee in East Java
}

\author{
Sri Tjondro Winarno ${ }^{1, *}$, Wiwik Sri Harijani ${ }^{2}$, Gyska Indah Harya ${ }^{1}$ \\ ${ }^{1}$ Department of Agribusiness, Faculty of Agriculture,UPN Veteran Jawa Timur, Surabaya, Indonesia \\ ${ }^{2}$ Department of Agrotechnology, Faculty of Agriculture, UPN Veteran Jawa Timur, Surabaya, Indonesia \\ "Corresponding author.Email: s_winarupn@yahoo.com
}

\begin{abstract}
Coffee is one of the most important plantation commodities in the world, where Indonesia is one of the four major groups of countries that export coffee to meet the world's needs. In East Java Robusta people's coffee has become part of the community to cultivate even with a low level of productivity, but for some other regions, Robusta people's coffee already has a fairly high level of productivity. The study was conducted in 5 districts which were Jember, Lumajang, Malang, Pasuruan, and Ngawi. Research respondents were those involved in the management of smallholder Robusta coffee from upstream to downstream. The results showed that there were four Robusta people's coffee marketing chains and involved 6 (six) actors involved.
\end{abstract}

Keywords: marketing chain, Robusta

\section{INTRODUCTION}

The people cultivate robusta coffee for a long time so it that there are already many plants in which their productivity has been decreased. The effort to increase the productivity of coffee plants is by replacing old plants with new varieties of plants. Short term program needs intensive maintenance on coffee plants with regular and scheduled maintenance which includes pruning, fertilizing, controlling pests and diseases using environmentally friendly biopesticides, picking ripe red fruits. Meanwhile, with the emergence of more coffee cafes, coffee shops and coffee shops both in rural and urban areas in almost all areas of East Java, the demand for coffee is increasing, directly proportional to the more creation of coffee processing facilities ranging from roasters to small-scale ground coffee making equipment.

The segmentation of the world coffee market is based on the nature of the product. The coffee market segment is divided into two, they are the commercial market segment and the special market segment. The commercial market is a type of market that trades coffee with an emphasis in terms of quantity or often referred to as the mainstream. Whereas the special market segment is a type of market that requires quality and taste in its trade so that coffee products are known as specialty coffee [1].

Coffee commodity has a bright prospect in the future. This is mainly seen from the prospects of an international market that tends to increase, thus providing opportunities for Indonesia to increase the export market share of coffee, both types of specialty and other processed coffee products. The development of specialty coffee with certain geographical indications and the diversification of processed coffee has a very important meaning because it can be a leading Indonesian commodity that has high competitiveness in the international market. The demands of world coffee consumers who want to taste back to nature coffee products such as roasted coffee and specialty coffee that are becoming a trend in major cities in the world make coffee has a brighter prospect in the future [2].

Stated that the price of a product is a measure of the bought product [3]. A consumer will dare to pay for a product at an expensive price if the value of satisfaction can be met and if the value of satisfaction is not met then he will not pay the product at a high price. External Market and Internal Market run effectively if customeroriented is the mediator [4]. Furthermore, said that the integration of marketing with a good marketing network can be used as a basis for developing marketing strategies [5]. The marketing mix provides a more meaningful way to identify and understand various customer segments [6]. Another benefit of the marketing mix is that it helps reveal another dimension of the work of marketing managers [7].

Specific brand helps accurate marketing and facilitates relations between producers and retailers [8]. The socialpsychological approach focuses on consumer attitudes, while the economic approach focuses on consumer desires while the sociological approach relies on the concept of consumer identity [9]. States that for low perceived quality customers, stressing on the importance of brand influence and price on purchase intentions [10]. High perceived quality customers show lower purchase value and perception influenced by self-confidence. The benefit of perception has a direct effect on temporary intention, ease of use is found to be indirectly related through perceived usefulness [11]. Social influence on consumers has a small but significant effect [12].

The purpose of this study was to analyze the Robusta people's coffee marketing chain in East Java. 


\section{METHODS}

The location of this study was determined intentionally (purposively), namely Jember, Lumajang, Malang, Pasuruan, and Ngawi Regencies by the consideration that they are districts that have smallholder Robusta coffee plantation areas, which on average have an area from 2009 to 2015. Each covers an area of 2,612.85 Ha; 2,702.67 Ha; and $8070.34 \mathrm{Ha} ; 9,725 \mathrm{Ha}$; and $321 \mathrm{Ha}$ (East Java Provincial Plantation Office, 2016). In addition to the area and location factors, another consideration is that those areas have coffee processing industries that are managed by farmer groups or farmers themselves. Sampling was carried out based on the consideration that the resource persons have the expertise and competence in accordance with the scope of the research, including coffee cultivation, processing, and marketing, as well as consumers. The technique of determining the sample units (respondents) used in this study uses a quota sampling technique which involves actors involved in value chain analysis including coffee MSMEs, related offices (Plantation Office and the Department of Industry and Trade Cooperatives) and 75 coffee farmers in Jember Regency, Lumajang, Malang, Pasuruan, Ngawi.

Interviews with related parties to smallholder Robusta coffee from upstream to downstream aim to collect coffee management data and identify problems that occur. Furthermore, this can be used as a reference to formulate an appropriate marketing strategy by minimizing the obstacles that occur.

\section{RESULTS AND DISCUSSION}

Smallholder Robusta coffee in East Java has a very large diversity in addition to locations with different heights, how to take care and how to harvest and processing fresh coffee fruit to green coffee beans (Green Bean). There are three ways of processing, which are the dry processing system and the wet processing system which is not fermented and the wet processing system which is fermented so that it will automatically influence the management strategy. In general, farmers still think that coffee cultivation is not the main occupation but only as a side job. The maintenance of coffee plants starts with the provision of manure/compost, NPK fertilizer, pest and disease control, and pruning of branches and twigs, including rarely done. This pruning has very significant benefits and impacts, especially on crop productivity including the quality of the coffee produced. In general, coffee farmers harvest by "plurut" between those that are still green and red are picked together simultaneously for reasons of efficiency. Though picking is very important because it will affect the quality, also post-harvest handling that must be adjusted to market demand. Efforts to make all activities of the production process from the cultivation of coffee plants, coffee fruit harvesting, coffee fruit processing, coffee bean processing, roasting, grinding, packaging, to marketing efficient, are expected to meet quality standards products at an efficient cost. Improving the quality of human resources of Robusta community coffee farmers, especially regarding the wellplanned and well-scheduled process of maintaining coffee plants. Improving the quality of coffee fruits and coffee beans by means of red picking and dry and wet processing systems to meet quality standards so that it can improve the bargaining position of smallholder Robusta coffee.

The results of the analysis of observations made on smallholder Robusta coffee business persons, there are 4 (four) channels of marketing chain and if it is observed from the four types of marketing chains, it involves 6 (six) parties who play roles in the smallholder Robusta coffee marketing chain in East Java. These parties are: 1) farmers; 2) middlemen; 3) collecting traders; 4) large traders; 5) coffee bean processing; 6) consumers.

This first marketing chain includes farmers as coffee producers; coffee bean processing; consumer. Farmers as producers because they do planting, harvesting coffee beans to the processing of coffee fruit activities, then the coffee bean processing businessman gets raw materials directly from farmers then do the roasting and grinding into ground coffee, so that the product is ready for consumers of robusta ground coffee.

The second marketing chain includes farmers; middlemen; collector traders; big traders and consumers. These robusta community coffee farmers get prices below the prices prevailing in the market. Generally, these middlemen provide prices by not differentiating the quality of coffee to be purchased. This condition causes coffee farmers to be less optimal in maintaining their crops and the work of farmers is finally considered as a side job rather than the main one. The collecting traders then handed over the crops to larger traders. These large traders submit to exporters and partly to local traders to be used as ground coffee. product is everything that is carried out, owned, used or consumed so that it can satisfy wants and needs including physical, service, goods, place of organization and ideas [3]. The product is a collection of tangible and non-tangible attributes [13].

The third marketing chain includes farmers; collector traders; wholesalers; consumers. The collector traders lend their means of production, in this case, fertilizer, to the farmers, with the note that the farmers must sell their coffee to the traders. Then the new traders sell their coffee in the form of coffee bean (green bean) and sell unprocessed coffee but have been sorted between those that have been red-cooked and those that are still green to large wholesalers and then to the final consumers. There 
are still many farmers who do not have knowledge about post-harvest handling, especially those who sell their coffee in the form of processed coffee (powder). It is important to increase the importance of understanding about coffee commodities to improve the bargaining position of coffee farmers who have relied heavily on middlemen. Based on management factors, coffee farmers do not have the knowledge of farming management, they aren't accustomed to the management of coffee plants from cultivation to market information, especially the issue of coffee prices. The new design of environmentally friendly packaging with suitable and good new materials is an integral part that is very important [14].

fourth marketing chain includes, farmers; collector traders; coffee bean processing; consumers. The collector traders lend their means of production, in this case fertilizer, to the farmers, with the note that the farmers must sell their coffee to the traders. This time it's just the coffee bean (green bean) from collectors traders are sold to coffee bean processors (from roasting to ground coffee) and then sold to consumers. The supply of quality raw materials is one of the keys to being able to provide added value, including coffee roasting. The aspects of Robusta coffee development should look up to the socio-economic aspects, especially the interests of farmers. Implementation of development should not only involve one stakeholder, but the need for collaboration between existing stakeholders [15]. Transactions carried out in the market are always followed by the transfer of goods and services in whole or in part which involves rights (property rights) between individuals of the contracting parties [16].

Conditions where a company enters one or more target markets with similar products, both in local, regional, national and global markets. There is a need for cooperation with institutions related to both government and private institutions, especially the specific products of each region in East Java. The relationship between perceived value and customer loyalty will be better understood by the perception of functional and symbolic value [17]. Stated that promotion is one-way info or promotions made to direct a person or organization to actions that create exchange and marketing [18]. While said that promotion is an activity that communicates product excellence [19]. Brand marketing communications will be able to sell products in competitive global markets [20]. Marketing communication has a significant effect on customer satisfaction and customer loyalty [21]

\section{CONCLUSION}

Based on the results of smallholder Robusta coffee marketing chain research, it can be concluded that in the four marketing chains found at the study site, it involved six parties including farmers, middlemen, collectors, large collectors, coffee bean processors, and consumers.

\section{REFERENCES}

[1] Aklimawati, L and Mawardi, S. 2016. Pemasaran Kopi. Kopi (Sejarah, Botani, Proses Produksi, Pengolahan, Produk Hilir, dan Sistem Kemitraan) Pusat Penelitian Kopi dan Kakao Indonesia. Penerbit. Gadjah Mada University Press. Hal : 803-823.

[2] Harisudin M. 2012. Keberhasilan kopi luwak dalam tinjauan integrasi strategi intensif. Simposium nasional ekonomi kopi. Kerja sama antara PERHEPI dengan Universitas Negeri Jember. Jember.

[3] Kotler P. 1995. Manajemen pemasaran. Translation of marketing management analysis, planning, implemantation, and control. Sevent edition. Prentice Hall International Inc. Penerbit Fakultas Ekonomi Universitas Indonesia.

[4] Saad NM, Hassan SH, and Shya LM. 2015. Revisiting The Relationship Between Internal Marketing and External Marketing: The Role Of Customer Orientation. The Journal of Developing Areas : 49 : 249-262.

[5] Guo X. 2013. Research on the Combination of Entity Marketing and Network Marketing. Applied Mechanics and Materials :427-429 : 2888-2892.

[6] Dinas Perkebunan Provinsi Jawa Timur. 2016. Laporan kerja dinas perkebunan Provinsi Jawa Timur Tahun 2015.

[7] Khan MT. 2014. The Concept of 'Marketing Mix' and its Elements. International Journal of Information, Business and Management : $6: 95-$ 107.

[8] Cain, P M. 2014. Brand management and the marketing mix model. Journal of Marketing Analytics : 2 :33-42.

[9] Andorfer VA, and Liebe U. 2012. Research on Fair Trade Consumption. A Review $J$ Bus Ethics :106:415-435.

[10] Porrala CC, and Mangin JPL. 2017. Store brands' purchase intention: Examining the role of perceived quality. European Research on Management and Business Economics : 23: 90-95.

[11] Azam MS, Quaddus M, and Lubna N. 2013. Behavioral modeling of the individual's acceptance and use of internet in Bangladesh: An analysis using an integrated approach. Journal of International Technology and Information Management $: 22: 78-83$. 
[12] Orzan G, Serban C, Iconaru C and Macovei OI. 2013. Modeling the Impact of Online Social Marketing Campaigns on Consumers' Environmentally Friendly Behavior. Research Journal of Recent Sciences : 2 :14-21.

[13] Seo S, Ahn HK, Jeong J and Moon J. 2016. Consumers' Attitude toward Sustainable Food Products: Ingredients vs. Packaging. Sustainability : 8:1-20.

[14] Zheng B. 2013. Green packaging materials and modern packaging design. Applied Mechanics and Materials : 271-272: 77-80.

[15] Suciati LP, Widkayanto and Wibowo R. 2008. Pemetaan dan pengembangan potensi kopi robusta berbasis evaluasi multikriteria di Kabupaten Jember. Research Grant IMHERE Project. Unej.

[16] Suciati LP, Rokhani, Amilia L 2012. Realitas masalah agency dalam kelembagaan tataniaga kopi rakyat di Jawa Timur. Simposium Nasional Ekonomi Kopi. Kerjasama antara PERHEPI dengan Universitas Jember, Jember 8 Nopember 2012.

[17] Chen PT and Hu HH. 2010. The effect of relational benefits on perceived value in relation to customer loyalty: An empirical study in the Australian coffee outlets industry. International Journal of Hospitality Management : 29: 405-412.

[18] Swastha B. 2000. Pengantar bisnis modern. (Pengantar ekonomi perusahaan modern). Liberty Yogyakarta. Yogyakarta.

[19] Kotler P. and Armstrong G. 2002. Prinsipprinsip pemasaran. Edisi 12. Penerbit Erlangga. Jakarta.

[20] Rehman SU, and Ibrahim MS. 2011. Integrated Marketing Communication and Promotion. International Refereed Research Journal :2: 187191.

[21] Dimyati M. 2015. The role of customer satisfaction in mediating marketing communication effect on customer loyalty. International Refereed Research Journal : $6: 72$ 81. 